\title{
Öğrenci Koçluğuna İlişkin Öğretmen ve Öğrenci Görüşleri: Bayburt Örneği ${ }^{1}$
}

\author{
Yrd. Doç. Dr. Figen ÇAM-TOSUN* \\ Bayburt Üniversitesi, Eğitim Fakültesi, Eğitim Bilimleri Bölümü, Bayburt / Türkiye \\ Yrd. Doç. Dr. Arslan BAYRAM \\ Artvin Çoruh Üniversitesi, Eğitim Fakültesi, Eğitim Bilimleri Bölümü, Artvin / Türkiye
}

\section{Öz}

$\mathrm{Bu}$ araştırmanın amacı, Bayburt ili ortaokullarında ve ortaöğretim kurumlarında uygulanmakta olan öğrenci koçluğuyla ilgili uygulamaya katılan öğretmenlerin ve öğrencilerin görüşlerini ortaya çıkarmaktır. Araştırmada nicel ve nitel araştırma yöntemleri birlikte kullanılmıştır. Araştırmanın nicel kısmında, evreni 482 öğretmen oluşturmaktadır, örneklem sayısı ise 215 olmuştur. Araştırmanın nitel kısmında, araştırmanın çalışma grubunu 22 öğretmen ve 24 öğrenci oluşturmaktadır. Araştırmacılar tarafindan öğrenci koçluğu ile ilgili hazırlanan bir anket ile öğretmen ve öğrencilerin öğrenci koçluğu konusundaki öznel değerlendirmesini alabilmek için yarı yapılandırılmış görüşme formları oluşturulmuştur. Anket elektronik ortamda, görüşme formları okullara gidilerek yapılmıştır. Verilerin analizinde Excel ve SPSS

\footnotetext{
${ }^{1}$ Araştırma merhalesinde, yardımlarını esirgemeyen Bayburt İl Milli Eğitim Şube Müdürü Sn. Hanefi Özbek'e teșekkür ederiz.

* Sorumlu Yazar. Tel: +90 4583332033

E-posta: figencam@hotmail.com

ORCID: 0000-0001-8303-2179

(C) 2017 Kalem Eğitim ve Sağlık Hizmetleri Vakfı. Bütün Hakları Saklıdır. ISSN: 2146-5606
} 
23.0 paket programı ile betimsel analiz tekniği kullanılmıştır. Elde edilen verilere göre öğretmenler öğrenci koçluğunu yararlı bulmakta ve öğrenciyi bütün yönleriyle (akademik, motivasyon, sosyal) desteklediğini, her kademede uygulanabilir olduğu$\mathrm{nu}$; fakat öğretmenlere fazladan iş yükü çıkardığını düşünmektedirler. Öğrenciler ise öğrenci koçluğu fikrini; olumlu ama uygulamayı yetersiz bulmaktadır.

Anahtar Kelimeler: Öğrenci koçluğu; Öğretmen; Öğrenci; Ortaokul; Ortaöğretim okulları.

\title{
Teacher and Student Perceptions of Student Coaching: Bayburt Example
}

\begin{abstract}
The purpose of this research study is to explore the opinions of teachers and students related to student coaching applied in secondary schools of Bayburt. In this study, quantitative and qualitative research methods are used together. In the quantitative portion of the study, 482 teachers constitute the population and the sample size is 215 . In the qualitative part of the study, working group of the study consists of 22 teachers and 24 students. A questionnaire and semi-structured interview forms have been created in order to obtain subjective evaluation of teachers and students related to student coaching. The questionnaire was administered electronically; interview forms were used through face to face communication. To analyze the data, Excel, SPSS 23.0 software package and descriptive analysis technique have been used. According to data obtained, teachers find student coaching useful and believe that it supports students in all aspects (academic, social), and it is applicable at all levels, however, it increases workload of teachers. Students find the idea of coaching useful; however, they find the practice insufficient.

Keywords: Student coaching; Teacher; Student; Middle school; Secondary schools.
\end{abstract}

\section{Extended Summary}

\section{Purpose}

The purpose of this research study is to explore the opinions of teachers and students related to student coaching applied in secondary schools of Bayburt. 


\section{Method}

In this study, quantitative and qualitative research methods are used together to explore the opinions of teachers and students related to student coaching applied in secondary schools of Bayburt. Quantitative design has been used to explore the opinions of teachers related to student coaching (Karasar, 2010).

In the quantitative portion of the study, semi-structured interview forms have been created in order to obtain subjective evaluation of teachers and students in secondary schools related to student coaching.

\section{Population, Sample and Working Group}

In the quantitative portion of the study, 482 teachers working at 26 secondary schools and 9 high schools of Bayburt in 2013-2014 constitute the population. The sample size is 215 considering acceptable margin of error of $5 \%$ in the population and a confidence level of $95 \%$ calculated for the tolerated error. However, the sample has reached 191. Accordingly, the margin of error was calculated as $5.52 \%$ taking confidence level as $95 \%$. In the qualitative part of the study, working group of the study consists of 22 teachers and 24 students.

\section{Development of Data Collection Tools}

A questionnaire consisting of 15 questions related to student coaching has been prepared by the researchers in the qualitative portion of the study. Personal questions have been employed in the first part of the questionnaire. 15 questions with answers related to student coaching have been given to teachers in the second part of the questionnaire and 10 different expressions have been given for their subjective evaluation. Semi-structured interview forms have been created in order to obtain subjective evaluation of teachers and students seperately related to student coaching.

\section{Data Collection}

The quaestionnaire was administered electronically. Taking the necessary permission from the Provincial National Education Directorate, questionnaires were sent to schools participating in link applications. Semi-structured interview forms have been used in order to coolect the quantitative data. Interview forms have been delivered to students and teachers and 
collected.

\section{Data Analysis}

To analyze the data, Excel, SPSS 23.0 software package and descriptive analysis technique have been used. Percent and frequency of each question in the survey were calculated. Chi-square test was performed to see if there was a relationship among the variables years of service, gender and education level. Descritive method has been used to analyze the quantitative data.

\section{Findings and Comments}

The majority of teachers believe that there should be implementation guidelines related to teaching students about coaching. Teachers also find student coaching useful and believe that it supports students in all aspects (academic, social), and it is applicable at all levels, however, it increases workload of teachers. Majority of them spend 1-3 hours a week with their students. Teachers regard teaching coaching as unnecessary and do not want such an implementation.

Chi-square test, which was done to see if there was a relationship among the variables years of service, gender and education level could not be interpreted.

Teachers have made their own evaluation about student coaching and given high scores. In practice, it is observed that the majority of teachers gave themselves 4 points out of 5 . Teacher ratio considering that the application of the weaknesses in the school is $32 \% .9$ students find coaching implemented sufficient, while 13 find it not sufficient. The number students who are satisfied with their coach is 19 , five students reported that they are not satisfied.

\section{Conclusion and Recommendations}

The fact that no training and guide about student coaching is given makes teachers believe coaching is not effective enough. The majority of teachers believe that it increases workload of teachers. They also believe that it is not applicable and they do not want it to be implemenetd for them even though it is applicable.

Teachers have made their own evaluation about student coaching and 
given high scores. In practice, it is observed that the majority of teachers gave themselves 4 points out of 5 . These results have proven significant.

More than half of the students seem to benefit from the student coaching, while others do not see coaching practice enough.

Before implementing such student coaching implementations, it is recommended to provide financial support, inform teachers and students about the application, and improve the infrastructure facilities in order to make the process applicable for the teachers.

\section{Giriş}

Çağa uygun insan yetiştirme amaciyla geleneksel öğretim yöntemleri terk edilerek bilim ve teknolojiden yararlanılarak yeni yöntemler geliştirilmektedir. Öğretim sağlanırken yeni bir öğretimsel liderlik türü olan "koçluk sistemi” kavramı ortaya çıkmıştır. Koçluk kelimesinin sözlükte "Kişilerin liderlik veya yöneticilik özelliklerini, becerilerini geliştirmeye yönelik, belli bir amacı hedefleyerek daha etkili sonuçlara ulaşmasını sağlamak üzere verilen hizmet" (TDK, 2014) anlamı taşıdığı görülmektedir.

Koçel (2001) koçluğu, yetiştirme ve geliştirmede kullanılan bir yöntem olarak tanımlamaktadır. Burada öğrenen aktiftir ve kontrollü bir biçimde öğrenilmektedir. Koç, öğreneni sürekli gözlemleyen; ama sürece müdahale etmeyen, öğreneni performansını ve güdülenmesini sağlayan, öğreneni yönlendiren ve özgüvenini artırandır. Koçluk sistemi birçok alanda ülkemizde de uygulanırken, son yıllarda eğitim koçluğu daha fazla önem kazanmıştır. Önceleri rehber öğretmen ve psikologlar bu işi yürütürken 2011-2012 öğretim yılında Millı̂ Eğitim Bakanlığı ortaokullar ve ortaöğretim (lise) okullarında çalışan öğretmenlerinde eğitim koçluğu yapmalarını isteyen bir genelge yayımlamış ve pilot uygulamalara başlamıştır.

Bilişsel koçluk bağımsız öğrenmeyi oluşturmaya çalışan düşünmeyi, düşünme hakkında bir yol olarak tanımlanmaktadır. Bu yol özellikle öğretmenlerin işlevsel araştırmaları kullanmaya çalıştığı bir süreçtir. Öğretmen burada öğretim süreçlerini değerlendirerek koçluk yapmaktadır (Demir ve Doğanay, 2009). 
Bilişsel koçluk; değerli bir meslektaşı bulunduğu yerden, olmak isteyeceği yere taşımaktır. Bilişsel koç öğrencinin algılamasını, kararlarını ve entelektüel fonksiyonlarını kuvvetlendirir. Bu türde içsel düşünce süreçlerinin değiştirilmesiyle öğrenmeyi güçlendirecek olan davranışlar için gerekli olan ön koşullar sağlanmış olacaktır (Costa ve Garmston, 1994; Aldrich, 2005, akt; Duman, 2013).

Öğretime yönelik bilişsel koçluk içeren yaklaşımlar; düşünsel süreçleri açıklar, bireylerde akademik başarılar için firsatlar sağlar, akademik başarı için hedef davranışları sunar ve iletişim ile etkileşimi arttırır (Paris ve Winograd, 1990, akt; Demir, 2009; Duman, 2013). Bilişsel koçluk yöntemi eğer öğrenciler hedeflere ve ortaya koydukları ürünlere yönelik sahiplik duygusu geliştirirlerse, öğretim faaliyetleri bireyin gelişimsel dönemlerine uygun yapılırsa, deneyimlere dayalı etkinliklerin içerisinde olursa, hem bağımsız öğrenme hem de işbirliği içerisinde karşılıklı bilgilendirici olursa ve öğrenci öğrenme durumunda aktif olursa etkili öğretimi arttırır (Brooks, 2000; Paris ve Winograd, 1990, akt; Demir, 2009; Duman, 2013).

Bilişsel koçluğun yarattığı bu değişim; anlamaya elverişli öğrencilerin, neyin söylenmekte olduğunu, ayrıca bilişsel koçlara neyin anlaşılmakta olduğunu anlamalarına izin verir ve böylece amaçlanan "bilgi içeriği" (Johnson ve Marrow, 1981, akt; Demir ve Doğanay, 2009) anlaşılmış ve iletilmiş olur. $\mathrm{Bu}$ nedenle istenen değişimi anlama yapılarını oluşturmada güvenilir işbirliği ilişkisi sürecinde dinleme, anahtar bir öneme sâhiptir. Foreman'a (1995) göre, "Bilişsel koçluk eşliğinde yargılamasız bir ortamda bu firsatların paylaşımı sağlandiğı takdirde büyüme, duyguların da ele alındığ bir süreç hâlini alır.” (akt; Demir ve Doğanay, 2009).

Bilişsel koçluk konusunda yapılan araştırmalar incelendiğinde, Costa ve Garmston (1994) bilişsel koçluğu kavramlaştıran araştırmacılar olduğu görülmektedir. Garmston, Linder ve Whitaker (1993) ise öğretmenleri bilişsel koçluk uygulamalarında öğretmenin ve öğrencilerin kapasitelerinin genişlediğini ortaya koymaktadır.

Eğitim bilimleri kapsamında bilişsel koçlukla ilgili alanyazın çoğunlukla, öğretmenlerin sınıf içi bilişsel koçluk uygulamalarına yöneliktir. $\mathrm{Bu}$ bağlamda "Bilişsel koçluk, düşünmeyi, problem çözmeyi, karar vermeyi ve kişisel kaynakları kullanmayı vurgular.” (Bal ve Demir, 2011). 
"Bilgi ve bilmenin sınırlarının, bilginin değişebilirliğinin, kesinliğinin ve bilme ölçütlerinin genellikle bireyler tarafindan yalnız başına olduklarında anlamalarının zorluğundan dolayı, bilişsel koçluğu öğrenme sürecini desteklemek için kullanılabilen bir strateji olarak görmek yerinde olacaktır." (Demir ve Doğanay, 2009).

Bilişsel koçluk görevini üstlenen öğretmenler öğrencilerle kurdukları güvene, karşılıklı bağlılığa ve sevgiye dayalı bir ilişkiyle öğrencileri kendi kendilerine değer veren bir konuma getirebilirler (Özden ve Doğanay, 2009).

Akademik koçluk, eğitim koçluğu, öğrenci koçluğu gibi kavramlar birbiri yerine oldukça sık kullanılan kavramlardır. "Akademik koçluk, ögrencilerin derslerdeki ve sinavlardaki başarılarını arttırmak için öğretmenler ve ögrencilerin birlikte gerçekleştirdiği bir takım çalışması olarak değerlendirilmektedir." (Karabacak, 2010). Bu çalışma Bayburt ilinde gerçekleştirilen bir projeye dayalı olarak gerçekleştirildiği için "öğrenci koçluğu” kavramı bu araştırmada kullanılmaktadır.

Bayburt Millî Eğitim Müdürlüğü’nde 2012-2013 eğitim-öğretim y1lında "Başarı İçin El Ele" projesi kapsamında "Öğrenci Koçluğu" ile ilgili çalışmalar, ortaokulda 8. sınıfları ortaöğretimde ise 12. sınıfları kapsayacak şekilde 429 öğretmen ve 1880 öğrenci ile başlamıştır. Uygulamanın ilk y1lında okullar arasında bazı farklılıklar görülmüştür. Bazı okullarda öğrenci koçları kendi sorumluluğundaki öğrencilerle haftada bir kez rutin olarak toplantı yaparak haftanın değerlendirmesini yaptığı, bazı okullarda ise öğrencinin ve öğrenci koçunun uygun olduğu boş zamanlarda görüştükleri ve problemlerini paylaştıkları görülmüştür. Temel derslerde günlük, haftalık ve aylık soru çözme hedefini de okullar kendilerine göre günlük haftalık ya da aylık olarak belirlemiştir. Dokuz okulda motivasyonu geliştirmek için etkinlikler yapıldığı, altı okulda kitap okuma takibi yapıldığı, dört okulda öğrenci için hedef belirleme yapıldığı görülmüştür.

2013-2014 eğitim öğretim y1lından itibaren ise öğrenci koçluğu ortaöğretimde 11 ve 12. sinıfları, ortaokulda ise 7 ve 8. sinıfları (482 öğretmen ve 2594 öğrenci) kapsamış ve öğrenci koçluğu için bir takım ilkeler benimsenmiştir. Bunlar şöyledir: Öğrencilerle her hafta düzenli olarak görüşülmesi, veli ziyareti yapılması, öğrencileri için özel ders çalışma programı oluşturulması, her deneme sınavı sonrası sınav sonuç analizi yapılarak öğrenci ve 
velisi ile paylaşılmasının yapılması ve eksikliği belirlenen konular hakkında gerekli plânlamanın yapılması, her öğrenci için hedef belirlemelerinin yapılması, her öğrenci için haftalık çözebileceği soru sayısı belirlenerek bunun takibinin yapılması, öğrencilerin motivasyonunu arttırıcı gezi, tiyatro vb. etkinlikler düzenlemesi, öğrencilerin farklı kaynaklardan soru çözmeleri sağlanarak farklı soru stillerine âşinâ olmalarının sağlanması, öğrencilerin y1l içerisinde okuyabilecekleri kitapları tespit ederek takibinin yapılması.

\section{Amaç}

$\mathrm{Bu}$ araştırmanın amacı, Bayburt ili ortaokullarında ve ortaöğretim kurumlarında uygulanmakta olan öğrenci koçluğuyla ilgili uygulamaya katılan öğretmenlerin ve öğrencilerin görüşlerini ortaya çıkarmaktır.

Bu çalışma Millî Eğitim Bakanlığı'nın okullarda uygulamak istediği öğrenci koçluğu ile ilgili yapılan uygulamalarda eksikliklerin ve öğrenci-öğretmenlerin beklentilerini ortaya koymak bakımından önemlidir.

$\mathrm{Bu}$ çalışmadaki bulgular öğrenci koçluğu ile ilgili gelecekte araştırmacıların ve Millî Eğitim Bakanlığı'nın yapacağı çalışmalara yol gösterici olacağı varsayıldığından, alana katkı sağlayacağı düşünülmektedir.

\section{Araştırma Modeli}

\section{Yöntem}

Bayburt ili ortaokullarında ve ortaöğretim kurumlarında uygulanmakta olan öğrenci koçluğuyla ilgili uygulamaya katılan öğretmenlerin ve öğrencilerin görüşlerini ortaya çıkarmak için nicel ve nitel araştırma yöntemleri birlikte kullanılmıştır. Araştırmada, öğretmenlerin öğrenci koçluğu ile ilgili görüşlerini ortaya çıkarmak için nicel araştırma yöntemi içinde deneysel olmayan; tutumlar, inanışlar, görüşler gibi bilgi türlerini belirlemede kullanılan tarama modeli kullanılmıştır (Karasar, 2010). Araştırmanın nitel boyutunda ise ortaokullarda ve ortaöğretim kurumlarındaki öğretmenlerin ve öğrencilerin öğrenci koçluğu konusundaki öznel değerlendirmesini alabilmek için görüşme formları kullanılmıştır.

\section{Evren, Örneklem ve Çalışma Grubu}

Araştırmanın nicel kısmında; araştırmanın evrenini, 2013-2014 öğretim y1lında Bayburt ortaokullarında (26 ortaokul) ve liselerinde (9 lise) görev yapan 482 öğretmen oluşturmaktadır. Evrenden kabul edilebilir hata payı 
$\% 5$, güven seviyesi $\% 95$ alınarak hesaplanan tolerans gösterilebilir hata için gerekli örneklem sayısı 215 olmuştur. Fakat ulaşılan örneklem 191 olmuştur. Buna göre güven seviyesi $\% 95$ alındığında hata payı \%5.52 olarak hesaplanmıştır. Tesadüfi örneklem yoluyla seçilmiştir. Örneklemin demografik özellikleri Tablo 1'de verilmiştir.

Tablo 1. Öğretmenlerin Demografik Özellikleri

\begin{tabular}{llcc}
\hline & & Frekans & Yüzde \\
\hline Cinsiyet & Kadın & 90 & 48.12 \\
& Erkek & 97 & 51.87 \\
\hline Hizmet y1lı & $1-5$ & 116 & 62.03 \\
& $6-10$ & 30 & 16.04 \\
& $11-15$ & 16 & 8.55 \\
& $16-20$ & 8 & 4.27 \\
& $20+$ & 17 & 9.09 \\
\hline Öğretim Kademesi & Ortaokul & 136 & 72.72 \\
& Lise & 51 & 27.27 \\
\hline
\end{tabular}

*Üç öğretmen demografik bilgilerini paylaşmamıştır.

Araştırmanın nitel kısmında; araştırmanın çalışma grubunu 22 öğretmen ve 24 öğrenci oluşturmaktadır. Çalışma grubu oluşturulurken, lise türlerine (Bayburt Anadolu Lisesi, Fen Lisesi ve Sağl1k Meslek Lisesi), cinsiyetlerine, çalışma yıllarına ve farklı branşta olmalarına dikkat edilmiştir. Ortaokullar ise sosyo-kültürel özelliklerine göre seçilmiştir (Bayburt Ortaokulu, Mahmut Kemal Yanbeğ Ortaokulu, Veysel Efendi Ortaokulu). Ortaokuldan seçilen çalışma grubunda da katılımcıların cinsiyetlerine, çalışma yıllarına ve farklı branşta olmalarına dikkat edilmiştir.

\section{Veri Toplama Aracının Geliştirilmesi}

Araştırmanın nicel kısmında; araştırmacılar tarafından öğrenci koçluğu ile ilgili 15 sorudan oluşan bir anket hazırlanmıştır. Anketin ilk kısmında öğretmenlere kişisel bilgileri sorulmuştur. Anketin ikinci kısmında ise öğretmenlere öğrenci koçluğu ile ilgili 15 soru sorulmuş, soruların altına seçenekler sunulmuştur ayrıca öz değerlendirmede bulunabilecekleri 10 ifade hazırlanmıştır. Hazırlanan anket uzman görüşüne (bir doçent, bir yardımcı doçent ve bir doktora öğrencisi) sunulmuştur. Uzman görüşleri alındıktan sonra eleştiriler ve katkılar dikkate alınarak anket düzenlenmiştir. 
Öğretmen ve öğrencilerin öğrenci koçluğu konusundaki öznel değerlendirmesini alabilmek için yarı yapılandırılmış görüşme formları oluşturulmuştur. Görüşme formları, öğretmenler ve öğrenciler için ayrı ayrı oluşturulmuştur. Görüşme formları da uzman görüşüne sunulmuştur. Uzman görüşleri alındıktan sonra eleştiriler ve katkılar dikkate alınarak görüşme formları düzenlenmiştir.

\section{Verilerin Toplanması}

Nicel verilerin toplanmasi; anketin elektronik ortamda yapılmasına karar verilmiştir. İl Millî Eğitim Müdürlüğü’nden gerekli izinler alınarak, anket linki uygulamaya katılan okullara gönderilmiştir.

Nitel verilerin toplanmas1; görüşmeleri gerçekleştirmek üzere, "yarı yapılandırılmış görüşme formları" kullanılmıştır. Araştırmanın amacına ulaşabilmek için tercih edilen ikinci veri toplama yöntemi olarak görüşme formlar 24.02.2014-28.02.2014 tarihleri arasinda belirtilen okullarda uygulanmıştır. Görüşme formları öğretmen ve öğrencilere elden dağıtılmış, doldurulduktan sonra toplanmıştır.

\section{Verilerin Çözümlenmesi}

Araştırmanın nicel kısmında elde edilen verilerin analizinde Excel ve SPSS 23.0 paket programı kullanılmıştır. Ankette yer alan her bir sorunun yüzde ve frekansları hesaplanmıştır. Soruların öğretmenlerin cinsiyeti, hizmet yılı ve öğretim kademesi arasında bir ilişki olup olmadığını görmek için ki-kare testi yapılmıştır. Araştırmada görüşmelerden elde edilen nitel verilerin analizinde betimsel analiz tekniği kullanılmıştır.

\section{Bulgular}

Öğretmenlerin "Öğrenci Koçluğu” hakkındaki görüşlerinin frekans ve yüzde dağılımlarını gösteren bulgular Tablo 2'de sunulmuştur.

Tablo 2. Öğretmenlerin Öğrenci Koçluğu Hakkındaki Görüşlerinin Frekans ve Yüzde Dağılımları

\begin{tabular}{llccc}
\hline Sorular & Seçenekler & F & \% & Cvpsz \\
\hline Öğrenci koçluğu yapacak & Evet gerekir. & 123 & 66.12 & \\
öğretmene, öğrenci koçluğu & Hayır gerekmez. & 61 & 32.79 & 5 \\
$\begin{array}{l}\text { ile ilgili bir öğretim yapmak } \\
\text { gerekir mi? }\end{array}$ & Diğer. Açıklayınız. & 2 & 1.07 & \\
\hline
\end{tabular}




\begin{tabular}{|c|c|c|c|c|}
\hline \multirow{3}{*}{$\begin{array}{l}\text { Öğrenci koçluğu yapacak } \\
\text { öğretmene, uygulama planı / } \\
\text { yönergesi verilmeli midir? }\end{array}$} & Evet verilmeli. & 150 & 81.52 & \multirow{3}{*}{7} \\
\hline & Hayır gerekmez. & 32 & 17.39 & \\
\hline & Diğer. Açıklayınız. & 2 & 1.08 & \\
\hline \multirow{3}{*}{$\begin{array}{l}\text { Öğrenci koçluğunu yararlı } \\
\text { buluyor musunuz? }\end{array}$} & Evet, yararlı buluyorum. & 137 & 74.45 & \multirow{3}{*}{7} \\
\hline & Hayır, yararlı bulmuyorum. & 41 & 22.28 & \\
\hline & Diğer. Açıklayınız & 6 & 3.26 & \\
\hline \multirow[t]{6}{*}{$\begin{array}{l}\text { Öğrenci koçluğu hangi } \\
\text { amaçla kullanılabilir? }\end{array}$} & $\begin{array}{l}\text { Öğrencide akademik başarıyı geliştir- } \\
\text { mek için }\end{array}$ & 15 & 8.06 & \multirow{6}{*}{5} \\
\hline & Öğrencide güven geliştirmek için & 5 & 2.68 & \\
\hline & Motivasyon geliştirmek için & 34 & 18.27 & \\
\hline & $\begin{array}{l}\text { Kendi kendine öğrenme becerisini } \\
\text { geliştirmek için }\end{array}$ & 7 & 3.76 & \\
\hline & Hepsi & 122 & 65.59 & \\
\hline & Diğer. Açıklayınız & 3 & 1.61 & \\
\hline \multirow{3}{*}{$\begin{array}{l}\text { Öğrenci koçluğunun } \\
\text { öğrencide akademik başarı } \\
\text { anlamında bir farklılık } \\
\text { oluşturduğunu düşünüyor } \\
\text { musunuz? }\end{array}$} & Evet, farkl1lık oluşturuyor. & 131 & 71.19 & \multirow{3}{*}{7} \\
\hline & Hayır, farklılık oluşturmuyor. & 47 & 25.54 & \\
\hline & Diğer. Açıklayınız. & 6 & 3.26 & \\
\hline \multirow{3}{*}{$\begin{array}{l}\text { Öğrenci koçluğunun ama- } \\
\text { cına ulaşması için öğrenci } \\
\text { ile güven duygusu } \\
\text { oluşturmak, yakınlık } \\
\text { kurmak gerekir mi? }\end{array}$} & Evet, gerekir. & 164 & 89.13 & \multirow{3}{*}{7} \\
\hline & Hayır, gerekmez. & 17 & 9.23 & \\
\hline & Diğer. Açıklayınız & 3 & 1.63 & \\
\hline \multirow{3}{*}{$\begin{array}{l}\text { Öğrenci koçluğu öğrenci ile } \\
\text { öğretmen arasındaki ilişkiyi } \\
\text { etkiler mi? }\end{array}$} & Evet etkiler & 161 & 86.55 & \multirow{3}{*}{5} \\
\hline & Hayır etkilemez & 23 & 12.36 & \\
\hline & Diğer. Açıklayınız & 2 & 1.07 & \\
\hline \multirow{3}{*}{$\begin{array}{l}\text { Öğrenci koçluğu yapmak } \\
\text { için ya da yaparken } \\
\text { öğrenciyi tanımak gerekir } \\
\text { mi? }\end{array}$} & Evet, gerekir. & 181 & 97.31 & \multirow{3}{*}{5} \\
\hline & Hayır, gerekmez. & 4 & 2.15 & \\
\hline & Diğer. Açıklayınız & 1 & 0.53 & \\
\hline \multirow{3}{*}{$\begin{array}{l}\text { Öğrenci koçluğu eğitimin } \\
\text { her kademesinde } \\
\text { uygulanabilir mi? }\end{array}$} & Evet, uygulanabilir. & 115 & 61.49 & \multirow{3}{*}{4} \\
\hline & Hayır, uygulanamaz. & 65 & 34.75 & \\
\hline & Diğer. Açıklayınız & 7 & 3.74 & \\
\hline
\end{tabular}




\begin{tabular}{|c|c|c|c|c|}
\hline \multirow{3}{*}{$\begin{array}{l}\text { Öğrenci koçluğu yapacak } \\
\text { öğretmenlerin özel } \\
\text { yetkinliklere sahip olması } \\
\text { gerekir mi? }\end{array}$} & Evet, gerekir. & 92 & 49.72 & \multirow{3}{*}{6} \\
\hline & Hayır, gerekmez. & 90 & 48.64 & \\
\hline & Diğer. Açıklayınız. & 3 & 1.62 & \\
\hline \multirow{3}{*}{$\begin{array}{l}\text { Öğrenci koçluğu } \\
\text { öğretmene yarar } \\
\text { sağllyor mu? }\end{array}$} & Evet, sağlamaktadır. & 106 & 56.98 & \multirow{3}{*}{5} \\
\hline & Hayır, sağlamamaktadır. & 76 & 40.86 & \\
\hline & Diğer. Açıklayınız & 4 & 2.15 & \\
\hline \multirow{3}{*}{$\begin{array}{l}\text { Öğrenci koçluğu öğretmene } \\
\text { fazladan iş yükü oluşturuyor } \\
\text { mu? }\end{array}$} & Evet, oluşturuyor. & 153 & 83.15 & \multirow{3}{*}{7} \\
\hline & Hayır, oluşturmuyor. & 24 & 13.04 & \\
\hline & Diğer. Açıklayınız & 7 & 3.8 & \\
\hline \multirow{4}{*}{$\begin{array}{l}\text { Öğretmenlere "öğretmen } \\
\text { koçluğu” yapılabilir mi? }\end{array}$} & Evet, yapılabilir & 66 & 35.67 & \multirow{4}{*}{6} \\
\hline & Hayır, yapılamaz & 43 & 23.24 & \\
\hline & Gereksiz görüyorum & 71 & 38.37 & \\
\hline & Diğer. Açıklayınız & 5 & 2.7 & \\
\hline \multirow{3}{*}{$\begin{array}{l}\text { Öğretmenlere "öğretmen } \\
\text { koçluğu” yapılmasını ister } \\
\text { misiniz? }\end{array}$} & Evet, isterim. & 54 & 29.34 & \multirow{3}{*}{7} \\
\hline & Hayır, istemem. & 126 & 68.47 & \\
\hline & Diğer. Açıklayınız & 4 & 2.17 & \\
\hline \multirow{4}{*}{$\begin{array}{l}\text { Öğrencinizle haftalık } \\
\text { ne kadar zaman } \\
\text { geçiriyorsunuz? }\end{array}$} & 1 saatten az & 24 & 12.56 & \multirow{4}{*}{14} \\
\hline & $1-3$ saat & 94 & 49.21 & \\
\hline & 4-6 saat & 20 & 10.47 & \\
\hline & Geçersiz & 39 & 20.41 & \\
\hline
\end{tabular}

Öğretmenlerin çoğunluğu (\%74) öğrenci koçluğunu yararlı bulmaktadır. Bununla birlikte yine çoğunluk (\%66) öğrenci koçluğu ile ilgili bir bilgilendirme ve (\%81) yönerge/uygulama plânı verilmesi gerektiğini düşünmektedir. Öğretmenlerin \%86'sı koçluğun öğrenci ile öğretmen arasındaki ilişkiyi etkilediğini düşünmektedir. Öğretmenlerin yarısı (\%49) koçluk yapmak için özel yetkinliklere sâhip olmak gerekmediğini ifade etmişlerdir. Öğretmenlerin büyük kısmı (\%83) koçluğun öğretmenin iş yükünü artırdığını söylemişlerdir. Öğretmenlerin yarıdan fazlası da (\%68) öğretmenlere koçluk yapılmasını istemediklerini ifade etmişlerdir.

Öğretmenlerin "Öğrenci Koçluğu” hakkındaki görüşlerini ortaya ç1karmak için sorulan soruların öğretmenlerin cinsiyeti, hizmet yılı ve öğretim kademesi ile bir ilişkisi olup olmadığını görmek için yapılan ki-kare testi 
anlamlı çıkmamıştır. Verilerin analizinde (ki-kare analizinde) beklenen değeri 5 'ten küçük olan gözenek sayısının toplam gözenek sayısının \%20'sini aştığ durumlar görülmüştür. $\mathrm{Bu}$ durumda anlamlılık testine ilişkin sonuçlar yorumlanamamıştır (Balc1, 2010; Büyüköztürk, 2010).

Öğretmenlerin yaptıkları öğrenci koçluğu ile ilgili kendilerini değerlendirmeleri istenmiştir. Elde edilen bulgular Tablo 3'te verilmiştir.

Tablo 3. Öğretmenlerin Öz Değerlendirmesi

\begin{tabular}{|c|c|c|c|c|c|c|c|}
\hline & 1 & 2 & & 3 & & 4 & 5 \\
\hline Koçluğunuzu d & $63 \%$ & $105 \%$ & 59 & $32 \%$ & 80 & $44 \%$ & $2513 \%$ \\
\hline $\begin{array}{l}\text { lanan öğrenci } \\
\text { / uygulamasını } \\
\text { l. }\end{array}$ & $168 \%$ & 191 & 40 & $22 \%$ & 60 & $33 \%$ & $25 \%$ \\
\hline $\begin{array}{l}\text { Okulunuzda uygulanan öğrenci } \\
\text { koçluğu sisteminin / uygulamasının } \\
\text { eksik yönleri olduğunu düşünüyo- } \\
\text { rum. }\end{array}$ & $137 \%$ & $2714 \%$ & 58 & $32 \%$ & 48 & $26 \%$ & $3519 \%$ \\
\hline rt- & $31 \%$ & $147 \%$ & 45 & $25 \%$ & 71 & $39 \%$ & $4625 \%$ \\
\hline Öğrenci başarısını & $42 \%$ & $2011 \%$ & 53 & $29 \%$ & 73 & $40 \%$ & $3117 \%$ \\
\hline $\begin{array}{l}\text { Öğrencinin motivasyonunu arttıra- } \\
\text { bildim. }\end{array}$ & $31 \%$ & $168 \%$ & 41 & $22 \%$ & 77 & $42 \%$ & $4524 \%$ \\
\hline $\begin{array}{l}\text { Öğrencinin } \mathrm{k} \\
\text { becerisini art }\end{array}$ & $73 \%$ & 21 & 59 & $32 \%$ & 65 & $35 \%$ & $3116 \%$ \\
\hline Öğrenciyi takip etmekte yeterliyim. & $105 \%$ & $179 \%$ & 58 & $31 \%$ & 68 & $37 \%$ & $3016 \%$ \\
\hline $\begin{array}{l}\text { Öğrenciyle görüşmeden önce ha- } \\
\text { zırlık yapiyorum. }\end{array}$ & 10 & 19 & 61 & $33 \%$ & 64 & $35 \%$ & $2815 \%$ \\
\hline $\begin{array}{l}\text { Öğrenciyle yeterli süre geçiriyo- } \\
\text { rum. }\end{array}$ & $147 \%$ & $2413 \%$ & 59 & $32 \%$ & 53 & $29 \%$ & $3117 \%$ \\
\hline
\end{tabular}

Tablo 3'te de görüldüğg̈ gibi öğretmenlerin öz değerlendirme puanlarına bakıldığında iki ifade hâriç diğer ifadelerde öğretmenlerin çoğunluğu kendisine 5 puan üzerinden 4 vermiştir. Bu ortalamalar öğretmenlerin öğrenci koçluğu konusunda kendilerini yeterli gördüğü anlamına gelmektedir. Öğretmenlerin 3 puan verdiği ifadeler ise şunlardır: "Uygulamada eksiklik olduğunu düşünüyorum ve ögrenciyle yeterli süre geçiriyorum.” 
Öğretmenlerin öğrenci koçluğu hakkındaki öznel görüşlerini alabilmek için kullanılan yarı yapılandırılmış görüşme formunda uygulamayla ilgili bir yönerge takip edip etmedikleri sorulmuştur.

Öğretmenler bu soruya çoğunlukla (19 öğretmen) yönerge, plân takip etmediklerini, fakat bir yönergenin olması gerektiğini (17 öğretmen) ifade etmişlerdir. Öğretmenlerden biri düşüncelerini şöyle açıklamıştır: "Plân yok. Ama olmalı. Elde ettiğimiz plânları uygulamaya çalışlyoruz. Herkes kendine göre bir plân buluyor ve onu uyguluyor." (Öğrt13)

Öğretmenlerin 19’u uygulanan koçluk sistemini yeterli bulmamıştır. Öğretmenlerin 12'si öğrenci koçluğunu yararlı bulurken, 10'u yararlı bulmadığını söylemiştir. Öğretmenlerden farklı görüşlere sâhip olan ikisinin ifadeleri şöyledir: "Çok fazla faydası olduğunu düşünmüyorum. Çünkü bunu uygulayacak vakti çok fazla bulamıyorum." (Öğrt11), "Evet. Öğrenci takip edildiğini biliyor, olumlu yansıyor, değerli olduğunu kavrıyor." (Öğrt21)

Öğretmenler öğrenci koçluğunun güven oluşturduğunu, akademik başarıyı arttırdığını ifade etmişlerdir. Bunun yanında öğretmenlerin 20'si iş yükü oluşturduğunu düşünmektedir. Öğretmenlerden biri şöyle açılamıştır: "Kesinlikle zaten işim başımdan aşkın ve kendi evimdeki çocuklara bile çok az zaman ayırabiliyorum.” (Öğrt18)

Öğretmenlere "öğretmenlik koçluğu” yapılabilir mi? Öğretmen koçluğu yapılmasını ister misiniz?" şeklinde sorulan soruya öğretmenlerin sadece altısı "Olabilir." şeklinde yanıtlamıştır. Diğer öğretmenler şiddetle karşı çıkmıştır. Bu öğretmenlerden farklı görüşte olan ikisi düşüncelerini şöyle ifade etmiştir: "Öğretmenlere ögretmenlik yapanlardan nefret ediyorum. Çünkü karşılarında öğretmen olduğunu unutup konuşuyorlar. Çoğunun slnıfta dizi titrer." (Öğrt18), "İsterim. Yeni atanan ögretmenlere yapılmasını isterim, uyum kurmak ve yeni iş ortamına alışma süreci olarak." (Öğrt16)

Uygulamaya katılan öğrencilere görüşme formunda öğrenci koçluğundan yararlanıp yararlanmadıkları sorulmuştur. Öğrencilerin 14'ü uygulamadan yararlandığını söylerken, 10’u yararlanmadığını söylemiştir. Öğrencilerden ikisi durumlarını şöyle açıklamıştır: "Evet yararlanabiliyorum. Haftada 3 gün toplantımız var, o günlerde çözdüğümüz soru sayısı, çözemediğimiz sorularl, okuduğumuz sayfa saylsl, bunların hepsinin raporunu ve- 
riyoruz." (Öğrc1), "Hayır, yeterli ilgiyi göremiyoruz ve düzenli bir programla koçlarımızla görüssemiyoruz. Görüşme ve yönlendirme yapılmıyor. Koçlartmızın ismi var sadece." (Öğrc22)

Öğrencilerden dokuzu uygulanan koçluğu yeterli görürken, 13'ü yeterli görmediğini dile getirmiştir. Öğrenciler, koçlarının kendilerine nasıl yardımcı olmasını istediği konusunda en fazla tekrar ettikleri ifade "Benimle daha çok ilgilenmesini isterim.” (9 öğrenci) olmuştur. Öğrencilerin öğretmenlerinden beklentileri konusunda diğer ifadeler şöyledir: "Sinav hakkında bilgi vermesini isterim.", "Sosyal aktiviteler düzenlemesini isterim.", "Ailemle görüşmesini isterim", "Sınav hakkında bilgi vermesini, test çözmesini isterim."

Öğrencilere en çok kaçıncı sınıfta koçluğa ihtiyaç duydukları sorulmuştur. Öğrencilerin en fazla tekrar ettikleri sınıflar şöyledir: Lise 4'te (11 öğrenci), okula başladığım dönemlerde (10 öğrenci), 8. sınıfta (7 öğrenci). Koçlarından memnun olan öğrenci 19 kişidir, 5 öğrenci ise memnun olmad1ğını ifade etmiştir.

Öğrencilerin 15'i koçlarını seçmek istediklerini, 9'u ise seçmek istemediğini ifade etmişlerdir. Seçmek istemediğini söyleyen öğrencilerde koçu olan öğretmeninden memnun olduğu için bu şekilde cevaplamıştır. "Koçunuzu seçmek ister miydiniz?" sorusunu cevaplayan bir öğrenci şöyle yazmıştır: "Hayır, öğretmenimi çok seviyorum." (Öğrc10)

\section{Tartışma ve Sonuçlar}

$\mathrm{Bu}$ araştırmada Bayburt ili ortaokullarında ve ortaöğretim kurumlarında uygulanmakta olan öğrenci koçluğuyla ilgili uygulamaya katılan öğretmenlerin ve öğrencilerin görüşlerini ortaya çıkarmak amaçlanmıştır. Öğretmenler öğrenci koçluğunu yararlı bulmakta, özellikle akademik başarıyı artıracağına inanmaktadır. Fakat uygulamadan kaynaklanan bazı eksiklikler olduğunu da düşünmektedirler. Öncelikle öğrenci koçluğu ile ilgili bir eğitim verilmemesi, öğretmenlere takip edecekleri bir yönergenin verilmemesi öğretmenlerin öğrenci koçluğunun yeterince etkili olmadığını düşünmelerine yol açmıştır.

Öğrenci koçluğu sadece akademik başarıyı kapsamadığından öğretimin her kademesinde uygulanabilmektedir, öğretmenler de bu fikri desteklemiştir. Fakat öğretmenlerin büyük kısmı öğrenci koçluğunun öğretmenlere fazladan 
iş yükü oluşturduğunu da düşünmektedirler. Öğretmenlerin büyük kısmının öğrencilere haftada 1-3 saat gibi kısıtlı bir zaman ayırdıkları görülmektedir.

Öğretmenlere öğretmen koçluğu sorulmuş, yapılabilir olsa da gereksiz olduğunu ve kendilerine bu uygulamanın yapılmasını istemedikleri ortaya çıkmıştır.

Öğretmenlerin öz değerlendirme verilerinde kendilerine ortalama 5 üzerinden 4 puan verdikleri görülmektedir. Bu sonuç mânidâr görülmüştür.

Öğrencilerin yarıdan fazlası öğrenci koçluğundan yararlanırken yine yarıdan fazlası uygulamayı yeterli görmemektedir. Öğrencilerin çoğunluğu koçlarından memnundur. Yine çoğunluğu koçlarını seçebilmeyi istemektedir. Uygulamadaki eksiklikler giderildiği takdirde daha fazla faydalanıp memnuniyet gösterecekleri düşünülmektedir.

Öğretmenlerden alınan hem nicel veriler hem de nitel veriler birbirini desteklemektedir. Öğrencilerden elde edilen veriler ise öğretmenden öğretmene değiştiğini söyledikleri için bu verilerde diğer verileri desteklemektedir.

Öğrenci koçluğu uygulamaları yapılmadan önce öğretmenlerin ve öğrencilerin uygulama hakkında bilgilendirilmesi, alt yapı olanaklarının iyileştirilmesi, öğretmenler için bu uygulamanın angarya gibi görülmesinin önüne geçilmesi önerilmektedir.

Millî Eğitim Bakanlığı'nın bu tür uygulamalara yaygın bir şekilde başlamadan önce pilot uygulamalar yapması, bu uygulamaların yansımalarına bakması gerekmektedir. Öğrenci ve öğretmen memnuniyetleri doğrultusunda yaygınlaşması sağlanmalıdır.

Öğrenci koçluğu ile ilgili deneysel araştırmalar yapılarak ihtiyaçlar, eksiklikler belirlenmeli, alana katkı sağlanmalıdır.

\section{Kaynakça}

Bal, A. P. ve Demir, Ö. (2011). Bilişsel koçluk yaklaşımının öğretmen adaylarının görüşleri açısından irdelenmesi. Ahi Evran Üniversitesi Kırşehir Eğitim Fakültesi Dergisi (KEFAD), 12(4), 325-340. 
Balcı, A. (2010). Sosyal bilimlerde araştırma yöntem teknik ve ilkeler. Ankara: Pegem Yayıncilik.

Büyüköztürk, Ş. (2010). Sosyal bilimler için veri analizi el kitabı. Ankara: Pegem Yayıncilık.

Brooks, G. R. (2000). Cognitive coaching training for master teachers and its effects on student teachers' ability to reflect on practice. Yayımlanmamış doktora tezi, Universty of Southern California Faculty of the Rossier School of Education.

Costa, L. A. ve Garmston, J. R. (1994). Cognitive coaching. www.overviewof ognitivecoaching--TheCenterforCognitiveCoaching

Demir, Ö. (2009). Bilişsel koçluk yöntemiyle öğretilen bilişsel farkındalık stratejilerinin altıncı sinif sosyal bilgiler dersinde ögrencilerin epistemolojik inançlarına, bilişsel farkındalık becerilerine, akademik başarılarına ve bunların kalıcılıklarına etkisi. Yayımlanmamış doktora tezi, Çukurova Üniversitesi Sosyal Bilimler Enstitüsü.

Demir, Ö. ve Doğanay, H. İ. (2009). Bilişsel farkındalık becerilerinin geliştirilmesinde bilişsel koçluk yaklaşımı. Educational Administration: Theory and Practice, 15(60), 601-623.

Duman, A. O. (2013). Bilişsel koçluk yönteminin yedinci sınıf sosyal bilgiler dersinde öğrencilerin akademik başarılarına ve demokratik tutumlarına etkisi. Yayımlanmamış yüksek lisans tezi, Niğde Üniversitesi Eğitim Bilimler Enstitüsü.

Garmston, R., Linder C. ve Whitaker, J. (1993). Reflections on cognitive coaching. Educational Leadership, 51(2), 57-60.

Karabacak. K. (2010). Akademik koçluk sisteminin öğrencilerin akademik başarısına etkisi. Sakarya Üniversitesi Eğitim Fakültesi Dergisi, 20, 81-94

Karasar, N. (2010). Bilimsel araştırma yöntemi. Ankara: Nobel Yayıncılık. 
Koçel, T. (2001). İşletme yöneticiliği. İstanbul: Beta Basım Yayım Dağıtım A.Ş.

Özden, D. ve Doğanay, A. (2009). Bilişsel farkındalık becerilerinin geliştirilmesinde bilişsel koçluk yaklaşımı. Educational Administration: Theory and Practice, 15(60), 601-623.

TDK. (2015). Büyük Türkçe sözlük, http://www.tdk.gov.tr/index.php?option=com_bts\&arama=kelime\&gu $\mathrm{id}=$ TDK.GTS.5593d0e3dd73f0.79136935. 